\title{
HYNAPENES A, B AND C, NEW ANTICOCCIDIAL AGENTS PRODUCED BY Penicillium sp.
}

\section{PRODUCTION, ISOLATION AND PHYSICO-CHEMICAL AND BIOLOGICAL PROPERTIES}

\author{
Noriko Tabata, Hiroshi Tomoda, Rokuro Masuma, Katsuj Haneda, \\ Yuzuru IWAI, and SATOSHI ŌMURA* \\ Research Center for Biological Function, The Kitasato Institute, \\ Minato-ku, Tokyo 108, Japan
}

(Received for publication August 27, 1993)

\begin{abstract}
Penicillium sp. FO-1611, a soil isolate, was found to produce a series of new anticoccidial compounds. Three active compounds, designated hynapenes $\mathrm{A}, \mathrm{B}$ and $\mathrm{C}$, were isolated from the fermetation broth of the producing strain by solvent extraction, silica gel column chromatography, gel filtration on Sephadex LH-20 and preparative HPLC. Hynapenes inhibited the growth of Eimeria tenella in an in vitro assay using BHK-21 cells as a host. No schizont in the cells was observed at concentrations ranging above $123 \mu \mathrm{M}, 34.7 \mu \mathrm{M}$ and $34.7 \mu \mathrm{M}$ for hynapenes A, B and C, respectively.
\end{abstract}

Recently, we have reported new anticoccidial agents of microbial origin, xanthoquinodins ${ }^{1)}$ and diolmycins ${ }^{2)}$. From our continuous screening system using BHK-21 cells as a host and monensin-resistant Eimeria tenella as a parasitic protozoan, a fungal strain FO-1611 was found to produce a series of new anticoccidial agents. Three active compounds, termed hynapenes A, B and C (Fig. 1), were isolated. In this paper, the taxonomy of the producing strain, fermentation, isolation, physico-chemical properties and biological characteristics of hynapenes are described.

\section{Characteristics of the Producing Strain}

Strain FO-1611 was originally isolated from a soil sample. For the taxonomic test of the fungus, potato dextrose agar, malt extract agar, CZAPEK's agar and yeast extract-soluble starch (YpSs) agar were used. This strain grew rapidly to form pale green colonies with diameter of $30 \sim 40 \mathrm{~mm}$ after incubation for 14 days at $25^{\circ} \mathrm{C}$. The colony surface was velvety. The conidial structures were abundantly produced on various agar media. The reverse color was pale gray to pale yellowish brown. When strain FO-1611 was grown on potato dextrose agar at $25^{\circ} \mathrm{C}$ for 7 days, the conidiophores borne from substrate hyphae, and penicillia were monoverticillate as shown in Fig. 2 . The phialides were $7.5 \sim 10 \times 2 \sim 3 \mu \mathrm{m}$. The conidia were globe to subglobe and $2.0 \sim 2.5 \mu \mathrm{m}$ in diameter, and its surface was smooth. From the above characteristics, the strain FO-1611 was identified as the genus Penicillium ${ }^{3,4)}$ and named Penicillium sp. FO-1611. This culture was deposited at the National Institute of Bioscience and Human-Technology (formerly the Fermentation Research Institute), Agency of Industrial Science and Technology Japan, as FERM P-13399.

\section{Fermentation}

A slant culture of strain FO-1611 grown on YpSs agar (soluble starch $1.5 \%$, yeast extract $0.4 \%$, $\mathrm{K}_{2} \mathrm{HPO}_{4} 0.1 \%, \mathrm{MgSO}_{4} \cdot 7 \mathrm{H}_{2} \mathrm{O} 0.05 \%$ and agar $2.0 \%, \mathrm{pH} 6.0$ ) was used to inoculate $500-\mathrm{ml}$ Erlenmeyer flasks containing $100 \mathrm{ml}$ of seed medium (glucose $2.0 \%$, yeast extract $0.2 \%, \mathrm{MgSO}_{4} \cdot 7 \mathrm{H}_{2} \mathrm{O} 0.05 \%$, 
Fig. 1. Structures of hynapenes A, B and C.<smiles>CC1CC(C)C2C(C1)C(O)C(O)C(C)C2(O)C=CC=CC(=O)O</smiles>

Hynapene A<smiles>CC1=C(/C=C/C=C/C(=O)O)C2C(C)CC(C)CC2CC1=O</smiles>

Hynapene B<smiles>CC1CC(C)C2C(=O)C(C)(C=CC=CC(=O)O)C=CC2C1</smiles>

Hynapene C
Fig. 2. Scanning electron micrograph of penicillia of strain FO-1611 on potato-dextrose agar (Hitachi, model S-430).

Scale: $5 \mu \mathrm{m}$.

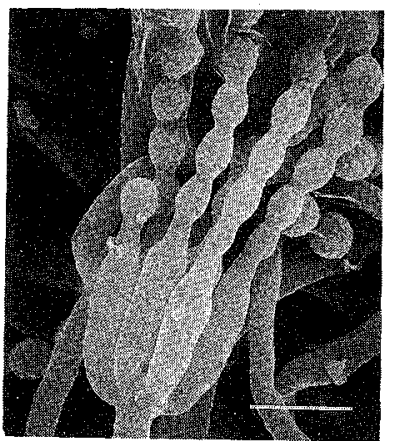

Fig. 3. A typical time course of hynapenes production.

$$
\text { Hynapenes A (•) and B (O). }
$$

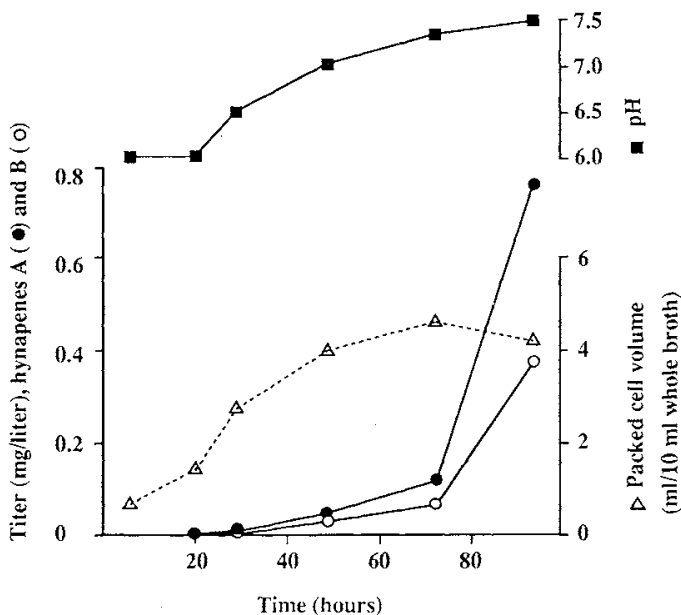

Polypepton $0.5 \%, \mathrm{KH}_{2} \mathrm{PO}_{4} 0.1 \%$ and agar $0.1 \%, \mathrm{pH} 6.0$ ). The flasks were shaken on a rotary shaker for 3 days at $27^{\circ} \mathrm{C}$. Two hundred $\mathrm{ml}$ of the seed culture was transferred into 20 liters of a production medium (sucrose $2.0 \%$, glucose $1.0 \%$, corn steep liquor $1.0 \%$, meat extract $0.5 \%, \mathrm{KH}_{2} \mathrm{PO}_{4} 0.1 \%, \mathrm{MgSO}_{4} \cdot 7 \mathrm{H}_{2} \mathrm{O}$ $0.05 \%$, trace elements $200 \mathrm{ml}$, (containing in g/liter: $\mathrm{FeSO}_{4} \cdot 7 \mathrm{H}_{2} \mathrm{O} 1.0, \mathrm{MnCl}_{2} \cdot 4 \mathrm{H}_{2} \mathrm{O} 1.0, \mathrm{ZnSO}_{4} \cdot 7 \mathrm{H}_{2} \mathrm{O}$ $\left.1.0, \mathrm{CuSO}_{4} \cdot 5 \mathrm{H}_{2} \mathrm{O} 1.0, \mathrm{CoCl}_{2} \cdot 2 \mathrm{H}_{2} \mathrm{O} 1.0\right), \mathrm{CaCO}_{3} 0.3 \%$ and agar $0.1 \%, \mathrm{pH} 6.0$ ) in a 30 -liter jar fermentor. The fermentation was carried out at $27^{\circ} \mathrm{C}$. A typical time course of the fermentation is shown in Fig. 3. The production of hynapenes A and B was measured by HPLC under the following conditions: column; YMC pack D-ODS-5 $(20 \times 250 \mathrm{~mm}), 60 \% \mathrm{CH}_{3} \mathrm{CN}$ in $0.05 \% \mathrm{H}_{3} \mathrm{PO}_{4}(0 \sim 10$ minutes $)$ and a linear gradient from $60 \% \mathrm{CH}_{3} \mathrm{CN}$ in $0.05 \% \mathrm{H}_{3} \mathrm{PO}_{4}$ to $100 \% \mathrm{CH}_{3} \mathrm{CN}$ (10 40 minutes), $\mathrm{UV}$ detection at $265 \mathrm{~nm}$, flow rate $6.0 \mathrm{ml} /$ minute. Under these conditions, hynapene $\mathrm{A}$ was eluted first with a retention time at 28.5 minutes, followed by hynapenes $B$ and $C$ at 29.5 and 35.5 minutes, respectively. The production of hynapenes $\mathrm{A}$ and $\mathrm{B}$ was observed after 30 hours and increased at least up to 93 hours. 
Table 1. Physico-chemical properties of hynapenes.

\begin{tabular}{|c|c|c|c|}
\hline & Hynapene A & Hynapene B & Hynapene $\mathrm{C}$ \\
\hline Appearance & Yellow powder & Yellow powder & Yellow powder \\
\hline$[\alpha]_{\mathrm{D}}^{23}(c 0.1, \mathrm{MeOH})$ & $-14^{\circ}$ & $+116^{\circ}$ & $+182^{\circ}$ \\
\hline Molecular formula & $\mathrm{C}_{18} \mathrm{H}_{28} \mathrm{O}_{5}$ & $\mathrm{C}_{18} \mathrm{H}_{24} \mathrm{O}_{3}$ & $\mathrm{C}_{18} \mathrm{H}_{24} \mathrm{O}_{3}$ \\
\hline \multicolumn{4}{|l|}{ HREI-MS $(m / z)$} \\
\hline Calcd: & 324.1935 & 288.1724 & 288.1724 \\
\hline Found: & 324.1926 & 288.1725 & 288.1724 \\
\hline $\mathrm{UV} \lambda_{\max }^{\mathrm{McOH}} \mathrm{nm}(\varepsilon)$ & $263(22,300)$ & $238(17,000), 297(16,700)$ & $\begin{array}{l}202(6,400), 252(12,200) \\
261(11,000)\end{array}$ \\
\hline IR $\left(\mathrm{cm}^{-1}\right)$ & $\begin{array}{l}3402,2920,1686,1637 \\
1543,1458,1406,1383 \\
1302,1248,1151,1011\end{array}$ & $\begin{array}{c}3421,2922,1660,1624 \\
1545,1454,1379,1306 \\
1259,1151,1063,1022\end{array}$ & $\begin{array}{l}2924,2389,1718,1691 \\
1633,1456,1416,1375 \\
1302,1265,1003\end{array}$ \\
\hline \multicolumn{4}{|l|}{ Solubility } \\
\hline Soluble: & $\begin{array}{l}\mathrm{MeOH}, \mathrm{CHCl}_{3}, \mathrm{EtOH}, \\
\text { EtOAc }\end{array}$ & $\begin{array}{l}\mathrm{MeOH}, \mathrm{CHCl}_{3}, \mathrm{EtOH}, \\
\text { EtOAc }\end{array}$ & $\begin{array}{l}\mathrm{MeOH}, \mathrm{CHCl}_{3}, \mathrm{EtOH}, \\
\text { EtOAc }\end{array}$ \\
\hline $\begin{array}{l}\text { Insoluble: } \\
\text { Color reaction }\end{array}$ & $\mathrm{H}_{2} \mathrm{O}$ & $\mathrm{H}_{2} \mathrm{O}$ & $\mathrm{H}_{2} \mathrm{O}$ \\
\hline Positive: & $50 \% \mathrm{H}_{2} \mathrm{SO}_{4}$ & $50 \% \mathrm{H}_{2} \mathrm{SO}_{4}$ & $50 \% \mathrm{H}_{2} \mathrm{SO}_{4}$ \\
\hline Negative: & Ninhydrin reagent & Ninhydrin reagent & Ninhydrin reagent \\
\hline
\end{tabular}

\section{Isolation}

The 93-hour cultured broth (20 liters) was extracted with 20 liters of ethyl acetate. The extracts were dried over $\mathrm{Na}_{2} \mathrm{SO}_{4}$ and concentrated in vacuo to dryness to yield a brown material $(6.54 \mathrm{~g})$. The material was applied on a silica gel column (E. Merck, Kieselgel 60, $300 \mathrm{ml}$ ). The column was washed with 1.5 liters of chloroform and 1.5 liters of chloroform-methanol $(99: 1)$. The active components were eluted with 1.5 liters of chloroform methanol (98:2), and each $150 \mathrm{ml}$ was successively collected. The 4th to 6th fractions enriched with hynapenes $\mathrm{A}, \mathrm{B}$ and $\mathrm{C}$ were combined and concentrated in vacuo to give a brown material (252 mg). Further purification of hynapenes was carried out by gel filtration on Sephadex LH-20 $(2 \times 120 \mathrm{~cm}, \mathrm{MeOH}, 0.2 \mathrm{ml} /$ minutes $)$. The active components were eluted with $500 \mathrm{ml}$ of methanol,
Table 2. Anticoccidial activity of hynapenes A, B and C in an in vitro assay.

Minimum effective concentration $(\mu \mathrm{M})$

\begin{tabular}{lcc} 
Compounds & \multicolumn{3}{c}{$\begin{array}{c}\text { Anticoccidial } \\
\text { activity }^{\mathrm{a}}\end{array}$} & Cytotoxicity $^{\mathrm{b}}$ \\
\hline Hynapene A & 123 & $\mathrm{NT}^{\mathrm{d}}$ \\
Hynapene B & 34.7 & 139 \\
Hynapene C & 34.7 & 69.4 \\
Monensin & $-{ }^{\mathrm{c}}$ & 0.03 \\
\hline
\end{tabular}

BHK-21 cells stained with hematoxylin solution was microscopically observed. In control experiments (no drug) infected sporocysts grew in the cells to form mature shizonts.

a No mature shizonts observed in the cells when the crug was added to the culture medium at the indicated concentrations.

b No BHK-21 cells observed when the drug was added to the culture medium at the indicated concentrations.

c No anticoccidial activity.

d NT: Not tested at higher concentrations than $123 \mu \mathrm{M}$ and each $2.5 \mathrm{ml}$ was successively collected. The 81 st to 91 st fractions enriched with hynapenes $\mathrm{A}, \mathrm{B}$ and $\mathrm{C}$ were evaporated in vacuo to give yellow materials $(86 \mathrm{mg})$. Hynapenes $\mathrm{A}, \mathrm{B}$ and $\mathrm{C}$ were finally purified by preparative HPLC (column; YMC pack D-ODS-5, $20 \times 250 \mathrm{~mm}$, solvent; $60 \% \mathrm{CH}_{3} \mathrm{CN}$ in $0.05 \% \mathrm{H}_{3} \mathrm{PO}_{4}$ $\left(0 \sim 10\right.$ minutes) and a linear gradient from $60 \% \mathrm{CH}_{3} \mathrm{CN}$ in $0.05 \% \mathrm{H}_{3} \mathrm{PO}_{4}$ to $100 \% \mathrm{CH}_{3} \mathrm{CN}(10 \sim 40$ minutes), UV at $265 \mathrm{~nm}, 6.0 \mathrm{ml} /$ minute). The active fractions were concentrated and extracted with ethyl acetate to give pure hynapenes A $(7.5 \mathrm{mg}), \mathrm{B}(3.8 \mathrm{mg})$ and C $(5.9 \mathrm{mg})$ as yellow materials 


\section{Physico-chemical Properties}

The physico-chemical properties of hynapenes A, B and C are summarized in Table 1. They are soluble in methanol, ethanol, acetonitrile, acetone, ethyl acetate, slightly soluble in chloroform and benzene and insoluble in water. The UV spectra show a maximum/maxima at $263 \mathrm{~nm}(\varepsilon 22,300)$ for hynapene A, at $238(\varepsilon 17,000)$ and $297 \mathrm{~nm}(\varepsilon 16,700)$ for hynapene B and at $202(\varepsilon 6,400), 252(\varepsilon 12,200)$ and $261 \mathrm{~nm}$ $(\varepsilon 11,000)$ for hynapene C. The IR spectra suggest the presence of a carbonyl group (carboxylic acid) in hynapenes $\left(1686 \mathrm{~cm}^{-1}\right.$ for hynapene $\mathrm{A}, 1660 \mathrm{~cm}^{-1}$ for hynapene $\mathrm{B}$ and $1691 \mathrm{~cm}^{-1}$ for hynapene $\mathrm{C}$ ).

\section{Biological Properties}

\section{Effect on Anticoccidial Activity in an In Vitro System}

Anticoccidial activity in vitro was assayed as reported previously ${ }^{1)}$. Anticoccidial activity of hynapenes is summarized in Table 2. Both hynapenes B and C showed anticoccidial activity at concentrations ranging above $34.7 \mu \mathrm{M}$. Hynapene A showed poor anticoccidial activity at concentration above $123 \mu \mathrm{M}$. When minimum effective concentrations were compared between anticoceidial activity (I) and cytotoxicity (II), the II/I ratio could be defined as specificity for anticoccidial activity. Hynapenes B and C showed the ratios of 4 and 2 , respectively.

\section{Other Biological Activities}

Antimicrobial activity of hynapenes was tested at $1 \mathrm{mg} / \mathrm{ml}$ by paper disc (i.d. $6 \mathrm{~mm}$, Toyo Roshi) method. Hynapenes A, B and C showed antimicrobial activity against Bacillus subtilis ATCC 6633 (diameter of inhibition zone: 10,12,11 mm), Mycobacterium smegmatis ATCC $607(0,17,0 \mathrm{~mm})$ and Pyricularia oryzae $(0,9,11 \mathrm{~mm})$, respectively. Hynapenes $\mathrm{A}, \mathrm{B}$ and $\mathrm{C}$ showed no antimicrobial activity against Staphylococcus aureus FDA 209P, Micrococcus luteus PCI 1001, Escherichia coli NIHJ, Escherichia coli NIHJ JC-2 IFO 12734, Pseudomonas aeruginosa P-3, Xanthomonas oryzae, Bacteroides fragilis ATCC 23745, Acholeplasma laidlawii PG8, Candida albicans, Saccharomyces sake, Aspergillus niger ATCC 6275, and Mucor racemosus IFO 4581.

\section{Discussion}

In the present investigation the hynapenes showed anticoccidial activity in an in vitro system. Hynapenes possess a common decalin core and a side chain of pentadienoic acid (Fig. 1). The structures will be reported in the following paper ${ }^{5}$. The order of anticoccidial activity was $\mathrm{B}=\mathrm{C}>\mathrm{A}$ (Table 1), suggesting the oxo group in the decalin core is important for potent anticoccidial activity. Furthermore, hynapene B showed the weakest cytotoxicity, resulting in the highest specificity among hynapenes. When production of hynapenes during fermentation was analyzed by HPLC, the peak corresponding to hynapene C (retention time of 35.5 minutes) was not detected. It might be that hynapene $\mathrm{C}$ is unstable after storage of the crude material at $-20^{\circ} \mathrm{C}$ for two months.

\section{Acknowledgment}

We express our thanks to Mr. T. KAWAKUBo for characterization of the producing strain and to Mr. M. KisHI for preparing oocysts of $E$. tenella.

\section{References}

1) Tabata, N.; Y. Suzumura, H. Tomoda, R. Masuma, K. Haneda, M. Kishi, Y. Iwai \& S. Òmura: Xanthoquinodins, new anticoccidial agents produced by Humicola sp. Production, isolation and physico-chemical and biological properties. J. Antibiotics 46: 749 755, 1993 
2) Tabata, N.; H. Tomoda, Y. Takahashi, K. Haneda, Y. Iwal, B. Woodruff \& S. Ōmura: Diolmycins, new anticoccidial agents produced by Streptomyces sp. I. Production, isolation and physico-chemical and biological properties. J. Antibiotics 46: 756 761, 1993

3) Pitt, J. I. (Ed.): The Genus Penicillium and Its Teleomorphic States, Eupenicillium and Talaromyces. Academic Press, 1979

4) Udagawa, S.; K. Tsubaki, G. Horie, K. Miura, K. Minoura, M. Yamazaki, T. Yokoyama \& S. Watanabe $(E d$.$) : Classification and identification of genus Penicillium. In Kinrui Zukan. II. pp. 1076 1120, Kodansha,$ Tokyo, 1978

5) Tabata, N.; H. Tomoda, Y. IwaI \& S. OMura: Hynapenes A, B and C, new anticoccidial agents produced by Penicillium sp. II. Structure elucidation. J. Antibiotics 46: 1854 1858, 1993 